\title{
Renewable Energy Consumption and Sectoral Based Output
}

\author{
Ibrahim Kabiru Maji ${ }^{a *}$, Mohd Yusof Saari ${ }^{b}$ \\ ${ }^{a}$ Department of Economics, Nigerian Army University Biu \\ ${ }^{\mathrm{b}}$ School of Business and Economics, Universiti Putra Malaysia \\ keibimaji@gmail.com
}

\begin{abstract}
The study explores the effect of renewable energy consumption on sectoral output in the presence of government effectiveness. A regressions method was used to analyze data from 1989 to 2019. The result revealed evidence of the positive and vital impact of renewable energy consumption on the sectoral output of the manufacturing and construction sectors. Although the elasticity of government effectiveness is neutral, trade openness has revealed evidence of positive and significant impact on sectoral outputs. However, population growth does not have a favourable impact on sectoral outputs. Furthermore, renewable energy consumption is not essential in determining the agricultural sector, transportation sector and other sectors. To quickly diversify the economy, policymakers should further increase awareness and provide more incentives for renewable energy in these sectors.
\end{abstract}

Key words: Renewable Energy; Sectoral Output; Effectiveness of Government.

\section{How to cite:}

Maji, I. K. \& Saari, M. Y. (2021). The impact of renewable energy consumption on sectoral based output in Nigeria. International Journal of Finance Research, 2(3). 143-153. DOI. https://doi.org/10.47747/ijfr.v2i3.339

\section{Introduction}

The need for sustainable economic growth and development has spurred the interest to increase the share of renewables in the total energy mix in economic activities in the African countries (UNFCCC, 2018). This is due to the vast potentials of renewable energy sources in the African sub-region. More importantly, renewable energy is a cleaner source of energy compared to other energy sources. However, access to a clean energy source for sustainable growth and development has remained a challenge to Nigeria and other African countries.

The following reasons inspire this study: The need to exploit the abundant renewable energy sources in Nigeria (solar, wind, hydropower, biomass); the fact that renewable energy can quickly be replenished within a relatively short period; the urge for sustainable economic growth process that does not compromise resource of the future generation; the paucity of studies on the nexus between renewable energy consumption and sectoral output in Nigeria such as, output 
from the manufacturing sector, constriction sector, agricultural sector, transportation sector, mining sector, wholesale and retail trade sector are yet to be examined.

First, despite that Nigeria is presently generating renewable energy from hydropower, solar, wind and biomass, there exists enormous potential of renewable energy that is yet to be harnessed. Renewable energy only accounts for about $18 \%$ of total energy utilization in Nigeria (ECN, 2018). This less usage of renewable energy has contributed to the current slow pace of gross domestic product growth rate at about 1.9\% since 2018. Second, unlike fossil fuel energy sources like petroleum, natural gas, and coal, renewable energy in Nigeria is not finite; it cannot quickly be exhausted.

Third, the use of renewable energy to achieve economic growth is sustainable, but fossil fuel energy depletes future generations' energy resources are not sustainable (EIA, 2017). About $80 \%$ energy source used for the economic growth process in Nigeria comes from non-alternative energy sources. Hence, there is a need for an urgent shift to renewable energies. Fourth, although recent studies have emerged on renewable energy and economic growth nexus in Nigeria (Oyedepo, 2012; Maji, 2015, Rafindadi, 2016; ENC, 2018; NBS, 2019), there is a scarcity of studies that examines the relationship between renewable energy and sectoral based output in Nigeria.

This study aims to investigate the impact of renewable energy on sectoral output in Nigeria in the presence of government effectiveness. The study considers sectoral output indicators from the manufacturing sector, constriction sector, agricultural sector, transportation sector, and other sectors to contribute to knowledge. Considering sectoral based output measurements enable the study to provide a sectoral based policy implication.

\section{Literature review}

The link between renewable energy and economic growth has recently occupied an important stage in the literature. Empirical studies relating to this nexus seems to be divided into three groups. One group of the study investigates the effect of renewable energy on economic growth (Chang et al., 2015). Another group of the study examines the impact of renewable energy and non-renewable energy on economic growth (Dogan, 2015). While the third group of the study considers a causal link between renewable energy and economic growth by emphasizing the four main hypotheses (Maji et al., 2019). However, investigating the relationship between renewable energy and sectoral output seems to have eluded literature.

The first group of literature that examines the relationship between renewable energy and economic growth have used a time series analysis (see Lin and Moubarak, 2014; Maji, 2015; Rafindadi and Ozturk, 2016). A similar relationship has also been investigated using a panel data analysis (Alper and Oguz 2016; Kahia et al., 2016; Bhattacharya et al., 2016; Amri, 2017; For instance, Maji (2015) employed a time series analysis for a study in Nigeria, while Alper and Oguz (2016) and Bhattacharya et al. (2016) used a panel analysis and found a positive and significant impact of renewable energy on the economic growth of their respective countries. On the other hand, Chang et al. (2015) and Amri (2017) found a bidirectional relationship between renewable energy and economic growth. 
Recent studies which do not include sectoral analysis of output in their investigation have also emerged (Bamati and Raoofi, 2019; Topcu and Tunsel, 2019; Bellakhal et al. 2019; Lee and Mccuskey, 2020). Renewable energy investment was assumed to be hindered by key governance factors (Bellakhal et al., 2019). After conducting an empirical investigation, the result reveals that higher institutional quality is essential to renewable energy investment of the countries. Furthermore, Topcu and Tugcu (2019) maintained that renewable energy consumption reduces income inequality; education level, age, gender and households' income are essential determinants of readiness to pay for renewable energy (Dogan and Muhammad, 2019). While renewable energy generation is an essential determinant of technology export in developed countries and not in developing countries (Bamati and Raoofi, 2019).

The second group of the literature has hinted at the impact of renewable energy and nonrenewable energy on economic growth (see Dogan, 2015; Kahia et al., 2016; Narayan and Doytch, 2017). In the presence of structural break, Dogan (2015) examines the relationship between renewable, non-renewable energy consumption and economic growth. While renewable energy consumption has an insignificant impact on economic growth, non-renewable energy consumption positively and significantly impacts economic growth. Similarly, Kahia et al. (2016) recently revealed evidence from Net Oil Exporting Countries (NOEC) that bidirectional causality exists between renewable energy and economic growth. The result further shows that substitutability exists between non-renewable and renewable energy types.

The third group of studies (Kahia et al., 2016; Rafindadi, 2016; Adewuyi and Awodumi, 2017; Maji et al., 2019) have paid attention to the four main hypotheses nexus between renewable energy and economic growth. These are the growth hypothesis, the conservation hypothesis, the unidirectional hypothesis and the neutral hypothesis (Kahia et al., 2016). The growth hypothesis maintains that renewable energy is among the energy source that facilitates economic growth. The conservation hypothesis posits that the urge for sustainable economic growth leads to the demand for renewable energy. The unidirectional hypothesis suggests that economic growth can cause renewable energy consumption, which can cause sustainable economic growth. On the other hand, the neutral hypothesis postulates that neither economic growth nor renewable energy causes each other (Maji et al., 2019).

Furthermore, this study contributes to the literature by using variables such as renewable energy consumption, government effectiveness, economic growth, trade openness, population and sectoral outputs. The selection of these variables has helped in differentiating this study from other existing studies. For instance, Dogan (2015), Kahia et al. (2016), Rafindadi and Ozturk (2016) and Narayan and Doytch (2016) all used the variables of economic growth, renewable energy consumption but do not consider institutional quality, trade openness, population and sectoral output variables. Similarly, Bhattacharya et al. (2016) used institutional quality but did not consider trade openness, population growth and sectoral outputs. However, trade openness is essential to capture globalization; the population is needed to capture the market and sectoral output to identify sectors that drive an economy. Therefore, analyzing renewable energy and sectoral output is scarce in the literature, thus establishing a research gap. This study intentions to address this gap by focusing on output from the manufacturing sector, constriction sector, agricultural sector, transportation sector and other sectors. 


\section{Methodology}

\subsection{Model and analytical tool}

The modelling framework of this study is the conservation theory of energy and economic growth nexus. The theory posits that economic growth is the key driver of energy consumption. As a result, the causal link runs from economic growth to energy consumption. However, to achieve sustainable economic growth, which does not compromise the resource of the future generation, the use of cleaner energy is required. Clean energy is that component of energy that can quickly be regenerated within a relatively short period without any adverse effect on humans and the environment.

The analytical tool for this study is the Ordinary Least Squares (OLS) regression analysis. The basis of employing the OLS is that it chooses the coefficients of a linear regression of a given independent variable using the principles of least squares that minimized the sum of squares of differences between a dependent variable and the explained variable of a regression function (Ibrahim and Chancharoenchai, 2015). This minimizes estimation errors and helps to avoid spurious results. Thus, resting on this analytical tool, sectoral outputs are specified as a function of renewable energy and other conditional variables. These variables include renewable energy consumption, government effectiveness, trade openness and population growth. The specification is presented in equation (1).

$s o_{t i}=f\left(r e c_{t}, g e f_{t}, g d p c_{t}\right.$, tro $\left._{t}, \operatorname{pog}_{t}\right)$

The logarithm of equation (1) was taken before converting it into an econometric form by including intercept and error. so represents sectoral output indicators, where the subscript $i$ denote the output of the manufacturing sector, construction sector, agricultural sector, transportation sector and other sectors. The error term needs to be normally distributed with zero mean and constant variance to be white noise.

$$
\begin{aligned}
& \text { lnso }_{t i}=f\left(\text { lnrec }_{t}, \text { lngef }_{t}, \text { lngdp }_{t}, \text { lntro }_{t}, \text { lnpog }_{t}\right) \\
& \text { lnso }_{t i}=\varphi_{0}+\varphi_{1} \text { lnrec }_{t}+\varphi_{2} \text { lngef }_{t}+\varphi_{3} \operatorname{lngdpc}_{t}+\varphi_{4} \text { lntro }_{t}+\varphi_{5} \operatorname{lnpog}_{t}+\vartheta_{t}
\end{aligned}
$$

Where $\operatorname{lnso}_{t i}$ denotes output from the manufacturing sector $\left(\operatorname{lnoms}_{t}\right)$, the output of the construction sector $\left(\operatorname{lnocs}_{t}\right)$, the output of the agricultural sector $\left(\operatorname{lnoas}_{t}\right)$, the output of the transportation sector $\left(\operatorname{lnots}_{t}\right)$ and other sectors $\left(\right.$ lnoos $\left._{t}\right)$. $\operatorname{lnrec}_{t}$ stands for renewable energy consumption, $\operatorname{lnge} f_{t}$ represents government effectiveness, $\operatorname{lng} d p c_{t}$ represent output per capita, lntro $_{t}$ denotes trade openness, $\operatorname{lnpog}_{t}$ is population growth. $\varphi_{0}$ is the intercept, $\varphi_{1}-\varphi_{5}$ are the coefficients of the explanatory variables, and $\vartheta_{t}$ is the error term.

We expect $\varphi_{1}-\varphi_{5}>0$, however, if renewable energy, government effectiveness, trade is not efficient then $\varphi_{1}-\varphi_{4}<0$. Similarly, if the population growth is not sustainable then $\varphi_{5}<0$. Thus, the study initially hypothesized that renewable energy consumption, government effectiveness, trade openness and population will have a positive effect on sectoral output 


\subsection{Data sources}

The dataset for this work is sourced from World Development Indicators (WDI), Word Governance Indicators (WGI) and United Nations Statistical Division (UNSD) from 1989 to 2019. The variables of sectoral output are measured as output from the manufacturing sector, output from the construction sector, output from the agricultural sector, output from the transportation sector and output from other sectors. The measurement for renewable energy is renewable energy consumption (\% of total final energy consumption); the measurement for government effectiveness is government effectiveness percentile rank; per capita output is measured as GDP per capita (constant 2010 US\$), trade openness is measured by trade (\% GDP) while population growth is measured as population growth $\%$ of the total. The availability of data limits this study. Therefore, the sectoral output considered in this study is the one in which data are available. The trend of variables is presented in Figure 1. Most variables in the figure have shown a moderate upward movement from inception up to 2019.

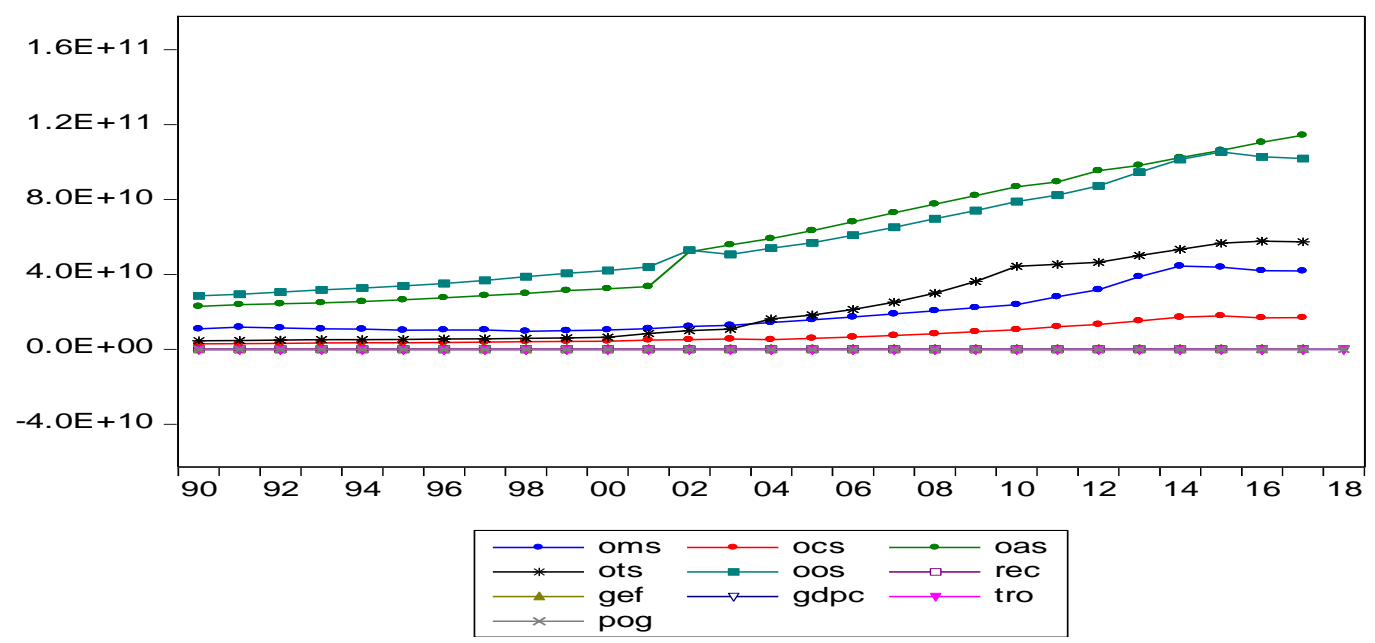

Figure 1. Trend of variables

\section{Result and discussion}

The result discussion begins with the presentation of the unit root test. The unit root test is a stationarity test that verifies the level of integration of the variables. If variables are stationary, it means that they are time-invariant. To avoid spurious results, a stationary test is necessary before conducting a regressions analysis. The unit root test was conducted on the variables using the Augmented Dickey and Fuller (1981) and Phillips and Perron (1988), and the result is presented in Table 1. The result suggests that all the variables are stationary, as indicated by the statistical level of significance in the footnote of Table 1. 
Table 1: Results of unit root test for renewable energy consumption and sectoral outputs

\begin{tabular}{|c|c|c|c|c|}
\hline \multirow[b]{2}{*}{ Variables } & \multicolumn{2}{|r|}{$\mathrm{ADF}$} & \multicolumn{2}{|r|}{$\mathrm{PP}$} \\
\hline & Level (0) & First difference (1) & Level (0) & First difference (1) \\
\hline \multirow[t]{2}{*}{$\operatorname{lnoms}_{t}$} & -0.487 & 0.348 & 0.923 & $-1.998 * *$ \\
\hline & $(0.879)$ & $(0.975)$ & $(0.994)$ & $(0.045)$ \\
\hline \multirow[t]{2}{*}{$\operatorname{lnocs}_{t}$} & 0.056 & -2.525 & 1.139 & $-1.837 *$ \\
\hline & $(0.956)$ & $(0.120)$ & $(0.996)$ & $(0.063)$ \\
\hline \multirow[t]{2}{*}{$\operatorname{lnoas}_{t}$} & 1.474 & $-4.436 * * *$ & 1.444 & $-4.426 * * *$ \\
\hline & $(0.998)$ & $(0.001)$ & $(0.998)$ & $(0.001)$ \\
\hline \multirow[t]{2}{*}{$\operatorname{lnots}_{t}$} & 0.073 & -2.536 & 1.142 & $-1.673 *$ \\
\hline & $(0.957)$ & $(0.118)$ & $(0.996)$ & $(0.088)$ \\
\hline \multirow[t]{2}{*}{$\operatorname{lnoos}_{t}$} & 0.732 & $-3.970 * * *$ & 0.653 & $-3.980 * * *$ \\
\hline & $(0.990)$ & $(0.005)$ & $(0.988)$ & $(0.005)$ \\
\hline \multirow[t]{2}{*}{$\operatorname{lnrec}_{t}$} & $-2.653 *$ & $-5.133 * * *$ & $-2.653 *$ & $-5.281 * * *$ \\
\hline & $(0.096)$ & $(0.000)$ & $(0.096)$ & $(0.000)$ \\
\hline \multirow[t]{2}{*}{$\operatorname{lnge} f_{t}$} & $-4.360 * * *$ & $8.875^{* * *}$ & $-4.304 * * *$ & $-8.875 * * *$ \\
\hline & $(0.001)$ & $(0.000)$ & $(0.002)$ & $(0.000)$ \\
\hline \multirow[t]{2}{*}{$\operatorname{lng} d c_{t}$} & -0.348 & $-2.928 * *$ & 0.370 & $-2.953 * *$ \\
\hline & $(0.905)$ & $(0.055)$ & $(0.902)$ & $(0.052)$ \\
\hline \multirow[t]{2}{*}{$\operatorname{lntro}_{t}$} & $-3.032 * *$ & $-4.995 * * *$ & $-3.032 * *$ & $-8.610 * * *$ \\
\hline & $(0.044)$ & $(0.000)$ & $(0.044)$ & $(0.000)$ \\
\hline \multirow[t]{2}{*}{$\operatorname{lnpog}_{t}$} & $-3.007 * *$ & -1.562 & -1.302 & -1.732 \\
\hline & $(0.047)$ & $(0.486)$ & $(0.614)$ & $(0.404)$ \\
\hline
\end{tabular}

Note: Values in parentheses (.) are $p$-values, $* * *, * *$ and $*$ indicate significance at $1 \%, 5 \%$ and $10 \%$ respectively.

After the unit root test, a descriptive statistic of the variables was presented in Appendix A. The Johansen cointegration test was further carried out to ascertain the long-run and equilibrium relationship between renewable energy and sectoral outputs. As presented in the lower part of Table 2, the result indicates that all the sectoral output models are cointegrated; as such, we can proceed with regression analysis. The regression analysis of the impacts of renewable energy consumption on sectoral output is also presented in the upper part of Table 2. The sectoral output results are presented in the following format. The presentation begins with output from the manufacturing sector $\left(\operatorname{lnoms}_{t}\right)$, output from the construction sector $\left(\operatorname{lnocs}_{t}\right)$, output from the agricultural sector $\left(\operatorname{lnoas}_{t}\right)$, output from the transportation sector $\left(\operatorname{lnot} s_{t}\right)$ and output from other sectors $\left(\operatorname{lnocs}_{t}\right.$ ) (see Maji and Adamu (2021) for renewable energy consumption and sectoral analysis).

Model 1 presents the impact of renewable energy consumption on sectoral output from the manufacturing sector. The finding reveals that renewable energy consumption has a positive and significant impact on the manufacturing sector's output. This suggests that an increase in renewable energy usage in the economic activities of the manufacturing sector will increase the output of the sector. This finding implies that despite that the manufacturing sector of the 
Nigerian economy is yet to be developed, the use of renewable energy will sustainably increase the sector's output towards achieving economic diversification. This finding is consistent with the work of Narayan and Doytch (2016). The result of government effectiveness is not significant, but population growth harms the manufacturing sector's output.

Table 2. Impact of renewable energy consumption and sectoral output

\begin{tabular}{|c|c|c|c|c|c|c|c|}
\hline \multirow{2}{*}{\multicolumn{2}{|c|}{ Sectoral outputs }} & \multicolumn{4}{|c|}{ Regression models } & \multirow{4}{*}{$\begin{array}{c}\operatorname{lnpog}_{t} \\
-6.148 * * * \\
(1.672)\end{array}$} & \multirow{4}{*}{$\begin{array}{r}\text { Constant } \\
-5.979 \\
(6.407)\end{array}$} \\
\hline & & \multirow{3}{*}{$\begin{array}{c}\text { lnrec }_{t} \\
3.384^{* * *} \\
(1.398)\end{array}$} & \multirow{3}{*}{$\begin{array}{c}\operatorname{lngef} f_{t} \\
-0.062 \\
(0.108)\end{array}$} & \multirow{3}{*}{$\begin{array}{c}\operatorname{lngdc_{t}} \\
2.789^{* * *} \\
(0.186)\end{array}$} & \multirow{3}{*}{$\begin{array}{l}\text { lntro } o_{t} \\
-0.125 \\
(0.956)\end{array}$} & & \\
\hline $\operatorname{lnoms}_{t}$ & 1 & & & & & & \\
\hline & & & & & & & \\
\hline $\operatorname{lncs}_{t}$ & 2 & $\begin{array}{c}4.155^{* *} \\
(1.804)\end{array}$ & $\begin{array}{l}-0.218 \\
(0.139)\end{array}$ & $\begin{array}{c}3.722 * * * \\
(0.239)\end{array}$ & $\begin{array}{l}0.225^{*} \\
(0.123)\end{array}$ & $\begin{array}{c}-11.803 * * * \\
(2.158)\end{array}$ & $\begin{array}{l}-12.879 \\
(8.269)\end{array}$ \\
\hline lnoas $_{t}$ & 3 & -1.301 & -0.052 & $3.138 * * *$ & $0.251^{*}$ & $-6.749 * * *$ & 12.568 \\
\hline $\operatorname{lnots}_{t}$ & 4 & $\begin{array}{c}2.935 \\
(2.379)\end{array}$ & $\begin{array}{l}-0.118 \\
(0.184)\end{array}$ & $\begin{array}{c}4.981 * * * \\
(0.316)\end{array}$ & $\begin{array}{c}0.374 * * \\
(0.163)\end{array}$ & $\begin{array}{c}-8.104 * * * \\
(2.847)\end{array}$ & $\begin{array}{l}-20.332 * \\
(10.908)\end{array}$ \\
\hline $\operatorname{lnoos}_{t}$ & 5 & $\begin{array}{c}1.366 \\
(1.445)\end{array}$ & $\begin{array}{l}-0.153 \\
(0.112)\end{array}$ & $\begin{array}{c}2.829 * * * \\
(0.192)\end{array}$ & $\begin{array}{c}0.251^{* *} \\
(0.098)\end{array}$ & $\begin{array}{c}-9.633^{* * *} \\
(1.729)\end{array}$ & $\begin{array}{c}6.043 \\
(6.624)\end{array}$ \\
\hline & & \multicolumn{4}{|c|}{ Diagnostic tests } & \multicolumn{2}{|c|}{ JC_test (Trace) } \\
\hline & & Nor & serl & Het & fun & $\mathrm{r} \leq 1$ & $r \leq 2$ \\
\hline lnoms $_{t}$ & 1 & $\begin{array}{c}0.038 \\
{[0.981]}\end{array}$ & $\begin{array}{c}2.063 \\
{[0.124]}\end{array}$ & $\begin{array}{c}2.884 \\
{[0.103]}\end{array}$ & $\begin{array}{l}18.809 \\
{[0.100]}\end{array}$ & $114.077 * * *$ & $69.457 * * *$ \\
\hline $\operatorname{lnocs}_{t}$ & 2 & $\begin{array}{c}0.137 \\
{[0.933]}\end{array}$ & $\begin{array}{c}3.106 \\
{[0.038]}\end{array}$ & $\begin{array}{c}0.577 \\
{[0.454]}\end{array}$ & $\begin{array}{c}3.781 \\
{[0.019]}\end{array}$ & $92.093 * * *$ & $47.918^{* *}$ \\
\hline $\operatorname{lnoas}_{t}$ & 3 & $\begin{array}{c}1.765 \\
{[0.413]}\end{array}$ & $\begin{array}{c}6.707 \\
{[0.102]}\end{array}$ & $\begin{array}{c}1.048 \\
{[0.417]}\end{array}$ & $\begin{array}{c}7.992 \\
{[0.001]}\end{array}$ & $121.522 * * *$ & $64.651 * * *$ \\
\hline $\operatorname{lnots}_{t}$ & 4 & $\begin{array}{c}0.814 \\
{[0.665]}\end{array}$ & $\begin{array}{c}0.847 \\
{[0.445]}\end{array}$ & $\begin{array}{l}1.734 \\
{[0.13]}\end{array}$ & $\begin{array}{c}3.525 \\
{[0.126]}\end{array}$ & $138.608 * * *$ & $67.463 * * *$ \\
\hline $\operatorname{lnoos}_{t}$ & 5 & $\begin{array}{c}1.623 \\
{[0.444]}\end{array}$ & $\begin{array}{c}3.873 \\
{[0.022]}\end{array}$ & $\begin{array}{c}1.288 \\
{[0.307]}\end{array}$ & $\begin{array}{c}0.895 \\
{[0524]}\end{array}$ & $108.422 * * *$ & $52.069 * *$ \\
\hline
\end{tabular}

Note: Values in parentheses (.) and [.] are standard errors and $p$ values respectively. ***,** and * represent significance at $1 \%, 5 \%$ and $10 \%$ respectively.Norm, serl, Het, and fun are diagnostic tests for normality, serial correlation, heteroskedasticity, and functional specification while JC_test stands for Johannsen cointegration test.

The impact of renewable energy consumption on the sectoral output of the construction sector is presented in Model 2 of Table 2. The result shows that renewable energy consumption has a positive and important impact on the construction sector's output, suggesting that higher renewable energy consumption facilitates more output from the sector. This implies that more renewable energy needs to be harnessed to increase output from the construction sector as a share of the total gross domestic product. Increasing the output of this sector will reduce over- 
reliance on crude oil and thus, provide the additional option of diversifying the economy to policymakers. This outcome corroborates the earlier empirical literature (Alper and Oguz, 2016; Narayan and Doytch, 2016). Moreover, the result of government effectiveness is not significant; trade openness reveals a positive impact on output from this sector while population growth adversely affects the construction sector's performance.

Furthermore, the result of models 3-5 shows that the relationship between renewable energy consumption and sectoral output from the agricultural sector, transportation sector and other sectors is not significant, indicating that the coefficient of renewable energy of these sectors does not have the statistical power to impact on output from these sectors. The finding implies low usage of renewable energy in economic activities in the agricultural, transportation and other sectors in Nigeria. Perhaps, the cost of renewable energy usage in these sectors at the moment may be too higher compared to the marginal benefit as such inefficient. Similarly, trade openness facilitates output of the agriculture, transportation and other sectors. However, population growth reveals evidence of reducing output from these sectors. This finding supports an earlier study (Dogan, 2015).

The diagnostic test results of Model 1-5 for normality, serial correlation, heteroskedasticity and functional specification are presented in the lower part of Table 2. The results passed most of the tests as suggested by the probability values in parentheses.

\section{Conclusion}

The study explores the relationship between renewable energy consumption and sectoral outputs in the presence of institutional quality in Nigeria. A regressions method was employed to analyze a sample of data for the period of 1989 - 2019. The result revealed evidence that renewable energy consumption has a positive and significant impact on the sectoral output of the manufacturing and construction sectors. However, renewable energy consumption is not important in determining the output of the agricultural, transportation and other sectors. Furthermore, the elasticity of government effectiveness is not significant, implying that government is less effective in the public and civil service and not independent from political pressure. Equally, trade openness has consistently revealed a positive and important impact on sectoral outputs. However, population growth does not have a favourable impact on all the sectoral outputs under consideration.

The implications of these findings are as follows. First, renewable energy importantly promotes economic activities in the manufacturing and construction sectors. Thus, policymakers should pay attention to renewable energy in these sectors as the main drivers of economic diversification in Nigeria. Second, the impact of renewable energy consumption is neutral in the agricultural sector, transportation sector and other sectors. This implies lower usage of renewable energy in these sectors; as such, policymakers should create awareness and provide more incentives to encourage the use of renewable energies in these sectors to achieve the government's objective of diversifying the economy. Third, the effect of government effectiveness is also neutral. This suggests the need to improve government presence in civil and public services and its independence from political pressures. Fourth, since trade openness positively affects sectoral outputs, policymakers should further leverage the comparative trade advantages from these 
sectors. Finally, further studies should consider other sectors and another measurement of renewable energy for new policy implications.

\section{References}

Alper, A., and Oguz, O. (2016). The role of renewable energy consumption in economic growth: Evidence from asymmetric causality. Renewable and Sustainable Energy Reviews, 60, 953-959.

Amri, F. (2017). Intercourse across economic growth, trade and renewable energy consumption in developing and developed countries. Renewable and Sustainable Energy Reviews, 69(October 2016), 527-534.

Adewuyi, A.O. and Awodumi, O.B. (2017). Renewable and non-renewable energy growthemissions linkages: Review of emerging trends with policy implications. Renew. Sustain. Energy Rev. 69, 275-291.

Bhattacharya, M., Paramati, S. R., Ozturk, I., and Bhattacharya, S. (2016). The effect of renewable energy consumption on economic growth: Evidence from top 38 countries. Applied Energy, 162, 733-741.

Bamati, N. and Raoofi, A. (2019). Development level and the impact of a technological factor on renewable energy production. Renewable Energy, https://doi.org/10.1016/j.renene.2019.11.098

Bellakhal, R., Ben, S., and Haffoudhi, H. (2020). Governance and renewable energy investment in MENA countries: How does trade matter? Energy Economics, 84(2019), 104541.

Chang, T., Gupta, R., Inglesi-Lotz, R., Simo-Kengne, B., Smithers, D., and Trembling, A. (2015). Renewable energy and growth: Evidence from a heterogeneous panel of G7 countries using Granger causality. Renewable and Sustainable Energy Reviews, 52, $1405-1412$.

Dogan, E. (2015). The relationship between economic growth and electricity consumption from renewable and non-renewable sources: A study of Turkey. Renewable and Sustainable Energy Reviews, 52, 534-546.

Dickey DA, Fuller WA (1981) Likelihood ratio statistics for autoregressive time series with a unit root. Econometrica, 49, 1057-1072.

EIA, 2017. Energy information administration of united states. Available at https://www.eia.gov.

ECN, (2018). National Energy Policy, Federal Republic of Nigeria [Draft Revised Edition].Available at www.energy.gov.ng/

Ibrahim, M. H., and Chancharoenchai, K. (2014). How inflationary are oil price hikes? A disaggregated look at Thailand using symmetric and asymmetric cointegration models. Journal of the Asia Pacific Economy, 19(3), 409-422. 
Vol. 2, No. 3, September 2021

Johansen, S. and Juselius, K. (1990). Maximum likelihood estimation and inference on cointegration-with applications to the demand for money. Oxford Bulletin of Economics and Statistics, 52, 0305-9049.

Kahia, M., Ben, M. S. and Charfeddine, L. (2016). Impact of renewable and non-renewable energy consumption on economic growth: New evidence from the MENA Net Oil Exporting Countries (NOECs). Energy, 116, 102-115.

Lee, J. and Mccuskey, M. (2020). Benefits of solar photovoltaic systems for low-income families in social housing of Korea: Renewable energy applications as solutions to energy poverty. Journal of Building Engineering, 28(October 2019), 101016.

Lin, B., and Moubarak, M. (2014). Renewable energy consumption - Economic growth nexus for China. Renewable and Sustainable Energy Reviews, 40, 111-117.

Maji, I. K. (2015). Does clean energy contribute to economic growth? Evidence from Nigeria. Energy Reports, 1, 145-150.

Maji, I.K. and Adamu, S. (2021). The impact of renewable energy consumption on sectoral environmental quality in Nigeria. Cleaner Environmental Systems, 2, 100009

Maji, I. K., Sulaiman, C. and Abdul-Rahim, A. S. (2019) Renewable energy consumption and economic growth nexus: A fresh evidence from West Africa. Energy Reports 5, (2019), 384-392.

Narayan, S. and Doytch, N. (2017). An investigation of renewable and non-renewable energy consumption and economic growth nexus using industrial and residential energy consumption. Energy Economics, 68, 160-176.

Oyedepo, S. O. (2012). Energy and sustainable development in Nigeria: the way forward. Energy, Sustainability and Society, 2, 15.

Phillips, P. C. B. and Perron, P. (1988). Testing for a unit root in time series regression. Biometrika, 75 (2), 335-346.

Rafindadi, A. A., and Ozturk, I. (2016). Impacts of renewable energy consumption on the German economic growth: Evidence from combined cointegration test. Renewable and Sustainable Energy Reviews, (January 2015)

Rafindadi, A. A. (2016). Does the need for economic growth influence energy consumption and $\mathrm{CO} 2$ emissions in Nigeria? Evidence from the innovation accounting test. Renewable and Sustainable Energy Reviews, 62, 1209-1225.

Topcu, M., and Tansel, C. (2019). The impact of renewable energy consumption on income inequality: Evidence from developed countries. Renewable Energy, https://doi.org/10.1016/j.renene.2019.11.103

UNFCCC (2018). United Nation Framework Convention on Climate Change. Available at http://unfccc.int/ 
Vol. 2, No. 3, September 2021

WDI (2019). World Bank's World Development Indicators. Available at http://www.worldbank.org/

WGI (2019). World Bank's World Governance Indicators. Available at http://www.worldbank.org/

\section{Appendix}

Appendix A: Descriptive statistics

\begin{tabular}{lcccccccccc}
\hline \multicolumn{1}{c}{ variables } & rec & gef & gdp & tro & pop & oms & ocs & oas & ots & oos \\
\hline Mean & 4.455 & 2.661 & 7.524 & 3.669 & 0.950 & 23.981 & 22.700 & 24.751 & 23.571 & 24.954 \\
Median & 4.458 & 2.729 & 7.543 & 3.692 & 0.954 & 23.865 & 22.550 & 24.867 & 23.6427 & 24.922 \\
Maximum & 4.486 & 3.048 & 7.849 & 3.975 & 0.986 & 24.580 & 23.616 & 25.348 & 24.867 & 25.559 \\
Minimum & 4.418 & 2.153 & 7.208 & 3.065 & 0.911 & 23.748 & 22.008 & 23.998 & 22.057 & 24.411 \\
Std. Dev. & 0.016 & 0.216 & 0.235 & 0.221 & 0.029 & 0.266 & 0.527 & 0.480 & 1.018 & 0.378 \\
Skewness & -0.566 & -0.650 & -0.074 & -0.862 & -0.119 & 1.344 & 0.412 & -0.417 & -0.167 & 0.134 \\
Kurtosis & 2.837 & 2.951 & 1.532 & 3.790 & 1.317 & 3.394 & 1.817 & 1.654 & 1.529 & 1.667 \\
Jarque-Bera & 1.090 & 1.414 & 1.812 & 3.002 & 2.407 & 6.150 & 1.7308 & 2.090 & 1.895 & 1.540 \\
Probability & 0.579 & 0.493 & 0.404 & 0.222 & 0.300 & 0.046 & 0.420 & 0.351 & 0.387 & 0.462 \\
Observations & 20 & 20 & 20 & 20 & 20 & 20 & 20 & 20 & 20 & 20 \\
\hline
\end{tabular}

\section{Copyrights}

Copyright for this article is retained by the author(s), with first publication rights granted to the journal.

This is an open-access article distributed under the terms and conditions of the Creative Commons Attribution license (http://creativecommons.org/licenses/by/4.0/) 